\title{
GRATITUDE CHARACTERISTIC ANALYSIS AND ITS INTERVENTION IN VARIOUS COUNTRIES IN THE GLOBALIZATION ERA
}

\author{
Fitra Marsela \\ Ms, Universitas Pendidikan Indonesia, Indonesia, \\ fitramarsela.fm@student.upi.edu
}

\begin{abstract}
The purpose of this study is to know about the characteristics of gratitude and development efforts (intervention) in individuals from 15 previous studies conducted in several countries. Information on the characteristics of gratitude is urgently needed by parents and teachers in and efforts to help children or students prepare for the challenges of globalization. The identifying process of this study through the journal search phase of the last 13 years (2003-2016) in electronic search, Elsevier, Springer, and Sage. The search keywords used are gratitude, gratitude in adolescence, and adulthood, and gratitude intervention in adolescents and adults. A total of 15 journals meet the criteria to be synthesized with coding procedure are used and developed to organize important information in each study. The result showed the characteristics of grateful individuals tend to have positive emotions, character strength and positive intuition. Gratitude can essentially be developed through integrative means and training processes such as the technique of list of gratitude, gratitude journals, behavioral expressions, and reflections stimulating gratitude given to the group format. The results of this study could be a contribution to the teachers and parents in preparing individuals who are able to compete in the globalization era.
\end{abstract}

Keywords: Gratitude, Youth, Globalization

\section{INTRODUCTION}

Global life increases human expectations of better status and quality of life, placing the mastery of knowledge and communication skills as the primary tool (Kartadinata, 1997). In line with that, Arif (2016: 70) also describes the characteristics of generations in globalization era tend to be more modern and have the characteristics of always thinking ahead, set targets, plan activities and develop gratitude. Gratitude to the individual has been present at birth and develops as the maturity of individual cognitive and emotional systems. Gratitude is assumed as one of the achievements of individual emotional maturity and attainment. Gratitude is manifested in feelings and behaviors of appreciating goodness in others and in yourself.

A research done by Graham \& Weiner (1986) underlies the assumption that the development of individual 
gratitude has existed in childhood and continues to develop in adolescence and adulthood. The study also suggests that few children (as many as 12\%) are under the age of 6 who would like to thank the person who gave them the candy while most children (ie more than $80 \%$ ) ages 7 years to 10 years say thank you in the same situation. The study also found that gratitude and appreciation for the good of individuals can be measured from the starting age of 7 years old to adults. Based on the description of the phenomenon and findings of the study, it can be concluded that gratitude at each phase of individual development starting from children, adolescents, and adults the trends can be measured.

Research on the importance of developing gratitude in adolescents has been disclosed through the findings of Froh (2008) and Lambert (2009) which suggests that gratitude in adolescents can have an impact on the emergence of positive behaviors such as life satisfaction, helpful behavior, psychological welfare, and prosocial behavior. In contrast, individuals who have low gratitude tend to be characterized by symptoms of anxiety and symptoms of depression, and ideas for suicide (Emmons \& McCullough, 2004; Li, 2004: Tsang, $\mathrm{J}, 2007$ ). Low gratitude in individuals in the globalization era is also characterized by the frequency of anxiety and discontent in reaching their life targets, such as thinking of bad things that are likely to pose a threat of success, complaining, low regiulity, narcissm (Watkins, Woodward, Stone, \& Kolts , 2003). Recent research in China reported that as many as $19.4 \%$ (243) adolescents who sampled the study thought about suicide and $8.0 \%$ (100) reported suicidal ideas and attempts when confronted with problems that put pressure on life (Li, 2014 ). In addition, the research of Flinchbaugh, Whitney, Moore, Chang \& May (2015) also addresses the gratitude that contribute to managing nature managing students' academic stress.

Gratitude is a compulsory thing that every individual have to achieve in this globalization era. The important reason for having gratitude is influenced by the demands of globalization that are identical with challenges and competition in various aspects of life such as education, economics, and employment. This study analyzes the characteristics and efforts of gratitude intervention from 15 previous studies conducted in several countries. Information on the characteristics of gratitude is urgently needed by parents and teachers in and efforts to help children or students prepare for the challenges of globalization.

\section{METHOD}

\subsection{Study Selection}

The identifying process of this study through the journal search phase of the last 13 years (2003-2016) in electronic search, Elsevier, Springer, and Sage. The search keywords used are gratitude, gratitude in adolescence, and adulthood, and gratitude intervention in adolescents and adults. A total of 15 journals meet the criteria to be synthesized. The selected study is based on the following criteria:

1.Participants of the study are individuals in the adolescent and adult phase (Age Range 12 years to 85 years).

2. This research uses quantitative approach that is experimental research (with treatment group and control group) and correlational research.

3. The efforts to increase gratitude through integrative intervention.

4. Gratitude interventions allow to be given to adolescent and adult individuals with experimental research design

5. Characteristics of gratitude can be observed through correlational studies from previous studies.

\subsection{Coding Procedure}

Coding documents are used and developed to organize important information in each study. The main items of the coding sheet are as follows: (1) year of issue; (2) publication sources (books, theses, journals); (3) the subject is taught; (4) duration of instruction; (5) the number of students in the study; (6) number of teachers in the study; (7) students' ability; (8) pupil age; (9) types of experimental controls; (10) Measurement achievements (Glass, 1982). Focus subjects of this study are individuals who have gratitude characteristics based on previous studies. Coding is also expected to facilitate researchers and readers in understanding every study analyzed in this study.

\section{RESULTS}

\subsection{Characteristics of Gratitude to Individuals}

\subsubsection{Positive Emotions}

The characteristics of grateful individuals tend to have positive emotions. Gratitude is closely attached to 
individual intelligence (Wilks, Neto, \& Mavroveli 2014; Geng, 2016). According to Arif (2014, pp. 71) gratitude is a typical feeling that arises when individuals receive kindness, compassion, love, benefits, and help from others. Based on the above opinion can be concluded that gratitude is a sense of gratitude for the contents of the life of the individual today without forgetting past experience. Feelings of gratitude are also inseparable from the influence of outsiders of individuals who have helped in the meaning of life like God, the universe, and surrounding people.

Emotions are often correlated with a period of individual existence. The emergence of positive emotions of gratitude does not doubt the time in the individual, but has become a permanent ability. This is in accordance with the opinion of Van Mechelen (Watkins, 2014, pp. 19) who suggested about the duration of gratitude in other individuals. Gratitude lasts a long time and settles on an individual who has experienced a meaningful event. A reinforced opinion in the Krause \& Hayward study (2014) that shows a great deal of worship performed over a long period of time will consistently enhance a healthy sense of gratitude and mentality. Gratitude as an emotion in the individual allows the individual to develop a good and good self-acceptance in living life as a personal, social, and religious being.

Gratitude has a connection with emotional intelligence, forgiveness, social welfare, subjective welfare in adolescents in various western (portugis), African (Cape Verde) and Beijing (Wilks, Neto, \& Mavroveli 2014; Geng, 2016) regions. In Indonesia in particular, research on the development of gratitude is also evolving, it is illustrated through research on the relationship of gratitude with other psychological aspects such as prosocial (Pitaloka \& Ediati, 2015). The study of factors that influence understanding of gratitude such as self-acceptance, knowledge, experience, appreciation, goodwill, good tendency, emergence of spiritual experience, and peaceful mind influence the formation of gratitude for the individual (Hambali, 2016).

\subsubsection{Character Strength}

Gratitude is also a character strength (Emmons\& Crumpler, 2000; Bartlett\& DeSteno,2006; Kruse, Chancellor, Ruberton, \& Lyubomirsky, 2014). The character strength is defined as the strong character attached to the individual. This is because gratitude is not an emotion but more than that it has become a part of the individual. Characteristics of individuals with low gratitude towards their life disposed to have negative emotions which reflects on the symptoms of anxiety, and symptoms of depression (Emmons \& McCullough, 2004; Tsang, J, 2007). Research which describes gratitude in this globalization era is vulnerable to anxiety and dissatisfaction in achieving life goals, such as thinking bad things which can be a threat of success, that is complaints, low religiosity, narcissistic (Watkins et al., 2003). Farwell research (1998) describes lowly narcissistic individuals in gratitude, while in a community that is having difficulty sharing their experiences and successful experiences.

Adult gratitude has also been learned by Neal Krause and Hayward (2014) who find gratitude to improve the quality of life at the end of life. This study conducted a survey of 1011 adults against the elderly in the United States. The most interesting findings are adults and elderly people who have more gratitude by visiting diligent churches, such as helping others, and having good health. While the elderly and the less grateful parents rarely go to church, rarely help others, have a tendency to struggle with others and do not care about God-given health. Based on the description of phenomena and research findings can be concluded gratitude at each stage of individual development ranging from children, adolescents, and adults, the trends can be measured. This becomes a reference in the development of doing comprehensive counseling guidance service strategy to develop adolescents' gratitude.

\subsubsection{Positive Intuition}

According to Arif $(2014$, pp. 85) gratitude is defined as one of the characteristics of the community. The example put forward is the characteristic of the people of Indonesia or the East has a tendency in terms of gratitude when compared with people in the western hemisphere. In everyday life, grateful individuals tend to be shunned from loneliness, anxiety, and depression. Conversely, individuals who do not feel gratitude in their daily lives tend to have negative emotions such as anxiety, exclusion, jealousy, disbelief to the people around, and disunity. The study of the community as a positive institution is illustrated by research (Naito, Wangwan, \& Tani, 2005) which illustrates the differences in gratitude in terms of cultural differences in Japanese and Thai students. This study found that Japanese male students tend to express their gratitude through facial expressions, verbal speech and have the motivation to do more prosocial deeds when compared with Thai students.

\subsection{Gratitude Intervention}

Gratitude can essentially be developed through integrative means and training processes. Several experimental studies discussed intervention efforts in developing gratitude for individuals (Froh, Kashdan, 
and Ozimkowski, 2009; Rash, Matsuba \& Prkachin, 2011; Flinchbaugh, Whitney, Moore, Chang, \& May, 2015). Implicitly, gratitude can be developed through the technique of list of gratitude, behavioral expressions, and reflections stimulating gratitude given to the group format (Rash, Matsuba \& Prkachin, 2011). Other findings also indicate that individuals who wrote thank-you letters to those who contributed to their lives had greater feelings of gratitude (Froh, Kashdan, \& Ozimkowski, 2009). In addition, the study of Flinchbaugh et al. (2015) also discusses the effect of giving gratitude journals to manage students' academic stress.

The need for developing gratitude in adolescents is increasingly consistent with the subject of research on developing gratitude in special populations such as disabilities, disaster victims, inmates (Galvin, R., 2004; Zhou, X., \& Wu, X., 2016; Wong, et al., 2017). In Indonesia in particular, Research on the development of gratitude is also developing (Pitaloka \& Ediati, 2015, Hambali, 2016). Research on gratitude intervention in Indonesia is also found in Dewanto \& Retnowati (2015) study that measures the influence of training on gestational and welfare interventions on people with physical disabilities. Treatment of interventions is done through special treatment such as daily duty, writing activities, reading activities and reflection activities

\subsection{Experimental Studies}

There are 4 experimental studies on gratitude intervention (Froh, JJ, Sefick, WJ, \& Emmons, RA, 2008; Froh, JJ, Kashdan, TB, Ozimkowski, KM, \& Miller, N., 2009; Rash, JA, Matsuba, MK, \& Prkachin, KM, 2011; Flinchbaugh, CL, Whitney, E., Moore, G., Chang, YK, \& May, DR 2015). In general, experimental research that addresses gratitude interventions can be done by giving a list of gratitude techniques, behavioral expressions, and reflections stimulating gratitude given to the group format, writing a journal of gratitude and writing a letter of gratitude.

\subsection{Correlational Studies}

There are 11 studies that discuss the relationship of gratitude with other behavioral variables such as positive emotions (Li, D., Zhang, W., Li, X., Li, N., \& Ye, B., 2012; Hlava, P., (Wilkins, Neto, \& Mavroveli, 2014) Character Strenght (Watkins, PC, Woodward, K., Stone, T., \& Kolts, RL, 2003; Neto, 2007; Kubacka, KE, Finkenauer, C., Rusbult, CE, \& Keijsers, 201; Krause, N., \& Hayward, R. D, 2014; Zhou, X., \& Wu, X, 2016 ) and Positive Intuition (Naito, T., Wangwan, J., \& Tani, M, 2005).

\section{DISCUSSION AND CONCLUSION}

The purpose of this study is to know about the characteristics of gratitude and development efforts (intervention) in individuals. Gratitude is the whole feeling of gratitude for the achievement of individual life in the present by not forgetting the precious experience of the past. Feelings of gratitude are also inseparable from the influence of parties outside the individual who has helped in the achievement of life like God, the universe, and surrounding people. Characteristics of individuals who have gratitude generally is to have a positive emotion, has a strong character, and has positive intuition. According to Robert A.Emmons (Arif, 2016, pp. 78) gratitude is beneficial in developing the physical, psychological, and social individual. Physical benefits include: (1) able to boost immunity; able to withstand pain; (2) lower blood pressure; (3) tend to be motivated to exercise and care for health; (4) creating quality sleep. Psychological benefits include: (1) improving positive emotions; (2) more alert and vibrant; (3) more joyful; (4) more optimistic and happier. Social benefits, including: (1) the formation of prosocial behaviors such as helpful, generous, and compassionate to others; (2) easily forgive others; (3) friendly and easy to socialize; (4) lack of feeling lonely and isolated. According to McCuellough (Watkins, 2014, pp. 17) aspects of gratitude consisting of (1) Intensity; (2) Frequency; (3) Span; (4) Density. In line with that Watkins et al. (2003) suggests aspects of gratitude consisting of (1) a sense of abudance; (2) appreciation of others; (3) appreciation of simple pleasure.

Gratitude tendencies in individuals can be measured through an instrument of gratitude. The most recent recommendation of the scale of gratitude is the scale of gratitude compiled by Watkins, Woodwart, Stone and Kolts (2003). The reason the researcher recommends the instrument is because the scale of gratitude compiled by Watkins et al. (2003) is the latest development of the instrument of gratitude which has been named the Gratitude, Resentment and Appreciation Test (GRAT). The aspects of gratitude or GRAT scale compilers include (1) sense of abundance; (2) appreciation of others; (3) appreciation of simple pleasure. These three aspects were developed based on the theory of gratitude developed by Philips C.Watkins. Here is a scale of Gratitude, Resentment and Appreciation Test (GRAT). 
Table: Research instrument

\begin{tabular}{|c|c|}
\hline Variable & Aspect \\
\hline \multirow{2}{*}{ Gratitude } & Sense of abundance \\
\cline { 2 - 2 } & Appreciation of others \\
\cline { 2 - 2 } & Appreciation of simple pleasure \\
\hline
\end{tabular}

The researches on gratitude are largely undertaken by people who struggle with the world of psychology. Interestingly, the study of gratitude is likely to develop within the scope of guidance and counseling research. This is in line with the opinion of Glading (Komalasari, $2011 \mathrm{pp} .14$ ) which states that the nature of guidance is preventive, ie the assistance provided to individuals in adapting and attaining personal, intellectual, social, emotional, and career development processes. Based on the context, group guidance is one of the guidance and counseling strategies capable of developing the knowledge and skills of the counselee on a developmental aspect such as the development of emotional aspects. Gratitude as one of the positive emotions is also very important possessed by individuals in globalization era that has characteristically tend to be more modern, thinking ahead, and always set targets. Through gratitude, the modern individual can gain psychological welfare, and avoid negative emotions such as anxiety, anger, and sadness.

\section{ACKNOWLEDGEMENT}

The author would like to acknowledge and express her greatest gratitude to the Indonesia Endowment Fund for Education (LPDP) for their support to her study. The author would also like to thank to Mr. Dr. Nandang Rusmana, M.Pd and Prof. Syamsu Yusuf, M.Pd for their assistance, advice, and support during her study.

\section{REFERENCE LIST}

Arif, S Iman. 2016. Psikologi Positif. Jakarta: Gramedia.

Bartlett, L., \& DeSteno, D. (2006). Gratitude and prosocial behavior. Psychol. Sci., 17(4), 319-325. https://doi.org/10.1111/j.1467-9280.2006.01705.

Dewanto, W., \& Retnowati, S. (2015). Intervensi Kebersyukuran dan Kesejahteraan Penyandang Disabilitas Fisik, 1(1), 33-47

Emmons, R. A., \& Crumpler, C.a. (2000). Gratitude as a Human Strength: Appraising the Evidence. Journal of Social and Clinical Psychology, 19(1), 56-69.

Emmons , R.A., \& McCullought,M.E.(2004). The Psychology of Gratitude. Oxford University.

Farwell, L., \& Wohlwend- Lloyd, R. (1998). Narcissistic Processes; Optimistic Expectations, Favorable Self Evaluations, and Self Enhancing Attributions. Journal of Personality, 66 (1),65-83

Flinchbaugh, C. L., Whitney, E., Moore, G., Chang, Y. K., \& May, D. R. (2015). Student Well-Being Interventions: The Effects of Stress Management Techniques and Gratitude Journaling in the Management Education Classroom. Journal of Management EducationJournal of Management Education, 36(2), 191-219. https://doi.org/10.1177/1052562911430062

Froh, J. J., Sefick, W. J., \& Emmons, R. A. (2008). Counting blessings in early adolescents: An experimental study of gratitude and subjective well-being. Journal of School Psychology, 46(2), 213-233.

Froh, J. J., Kashdan, T. B., Ozimkowski, K. M., \& Miller, N. (2009). Who benefits the most from a gratitude intervention in children and adolescents? Examining positive affect as a moderator. The Journal of Positive Psychology, 4(February 2013), 408-422. https://doi.org/10.1080/17439760902992464

Galvin, R. (2004). Challenging the Need for Gratitude: Comparisons Between Paid and Unpaid Care for Disabled People. Journal of Sociology, 40(2), 137-155. https://doi.org/10.1177/1440783304043453 
Geng, Y. (2016). Gratitude mediates the effect of emotional intelligence on subjective well-being: A structural equation modeling analysis. Journal of Health Psychology, (3). https://doi.org/10.1177/1359105316677295

Glass, GG. (19820. Approach to the synthesis of research result,19(2), 93-112.

Graham, S., \&Weiner, B. (1986). From an attributional theory of emotion to developmental psychology: A round trip ticket? Social Cognition, 4, 152-179

Hlava, P., \& Elfers, J. (2013). The Lived Experience of Gratitude. Journal of Humanistic Psychology, 22167813508605. https://doi.org/10.1177/0022167813508605

Hambali, A. (2016). Faktor-Faktor Yang Berperan dalam Kebersyukuran (Gratitude) Pada Orangtua Anak Berkebutuhan Khusus Perspektif Psikologi Islam. Jurnal IImiah Psikologi. (105), 94-101.

Hwang, H., Kang, H., Tak, J., \& Lee, S. (2015). Impact of Self-esteem and Gratitude Disposition on Happiness in Pre-service Early Childhood Teachers. Procedia - Social and Behavioral Sciences, 174, 3447-3453. https://doi.org/10.1016/j.sbspro.2015.01.1017

Kartadinata, Sunaryo. (1997) Pendidikan Untuk pengembangan SDM Bermutu. Makalah Konvensi bersama Divisi-divisi IPBI (IPKON,IGPI, ISKIN,IIBKIN). Purwekerto. 11-14 Desember ,1997.

Komalasari, Gantina. 2011. Teori dan Teknik Konseling. Jakarta: Indeks

Kruse, E., Chancellor, J., Ruberton, P. M., \& Lyubomirsky, S. (2014). An upward spiral between gratitude and humility. Social Psychological and Personality Science, 5(7), 805-814. https://doi.org/10.1177/1948550614534700

Krause, N., \& Hayward, R. D. (2014). Hostility, Religious Involvement, Gratitude, and Self-Rated Health in Late Life. Research on Aging, 36(6), 731-752.

Lambert, N. M., Graham, S. M., \& Fincham, F. D. (2009). A prototype analysis of gratitude: varieties of gratitude experiences. Personality and Social Psychology Bulletin, 35, 1193-1207. https://doi.org/10.1177/0146167209338071

Li, D., Zhang, W., Li, X., Li, N., \& Ye, B. (2012). Gratitude and suicidal ideation and suicide attempts among Chinese Adolescents: Direct, mediated, and moderated effects. Journal of Adolescence, 35(1), 55-66. https://doi.org/10.1016/j.adolescence.2011.06.005

Li, S. (2014). How to Make a Grateful Child? Reflection on Gratitude Campaigns in China in Recent Years. SAGE Open, 4(4). https://doi.org/10.1177/2158244014559017

Naito, T., Wangwan, J., \& Tani, M. (2005). Gratitude in University Students in Japan and Thailand. Journal of Cross-Cultural Psychology, 36(2), 247-263. https://doi.org/10.1177/0022022104272904

Neto, F. (2007). Forgiveness, personality and gratitude. Personality and Individual Differences, 43(8), 23132323. https://doi.org/10.1016/j.paid.2007.07.010

Pitaloka, D. A., \& Ediati, A. (2015). Rasa syukur dan kecenderungan perilaku prososial pada mahasiswa fakultas psikologi universitas diponegoro, 4(April), 43-50

Rash, J. A., Matsuba, M. K., \& Prkachin, K. M. (2011). Gratitude and well-being: Who benefits the most from a gratitude intervention? Applied Psychology: Health and Well-Being, 3(3), 350-369.

Tsang,J, (2007). Grtitude for small and large favors: Abehavioral test. Journal of Positive Psychology,2,157167.

Watkins, C. Philips . (2014) Gratitude and the Good Life. Washington: Springer

Watkins, P. C., Woodward, K., Stone, T., \& Kolts, R. L. (2003). Gratitude and Happiness: Development of a Measure of Gratitude, and Relationships With Subjective Well-Being. Social Behavior and Personality: An International Journal, 31(5), 431-451. Watkins, C. Philips . (2014) Gratitude and the Good Life. Washington: Springer

Wilks, D. C., Neto, F., \& Mavroveli, S. (2014). Trait emotional intelligence, forgiveness, and gratitude in Cape Verdean and Portuguese students. South African Journal of Psychology, 45(1), 93-101. https://doi.org/10.1177/0081246314546347

Wong, Y. J., Gabana, N. T., Zounlome, N. O. O., Goodrich Mitts, N., \& Lucas, M. (2017). Cognitive correlates of gratitude among prison inmates. Personality and Individual Differences, 107, 208-211. 
https://doi.org/10.1016/j.paid.2016.11.043

Zhou, X., \& Wu, X. (2016). Understanding the roles of gratitude and social support in posttraumatic growth among adolescents after Ya'an earthquake: A longitudinal study. Personality and Individual Differences, 101, 4-8. https://doi.org/10.1016/j.paid.2016.05.033

\section{Summary of Study Characteristic}

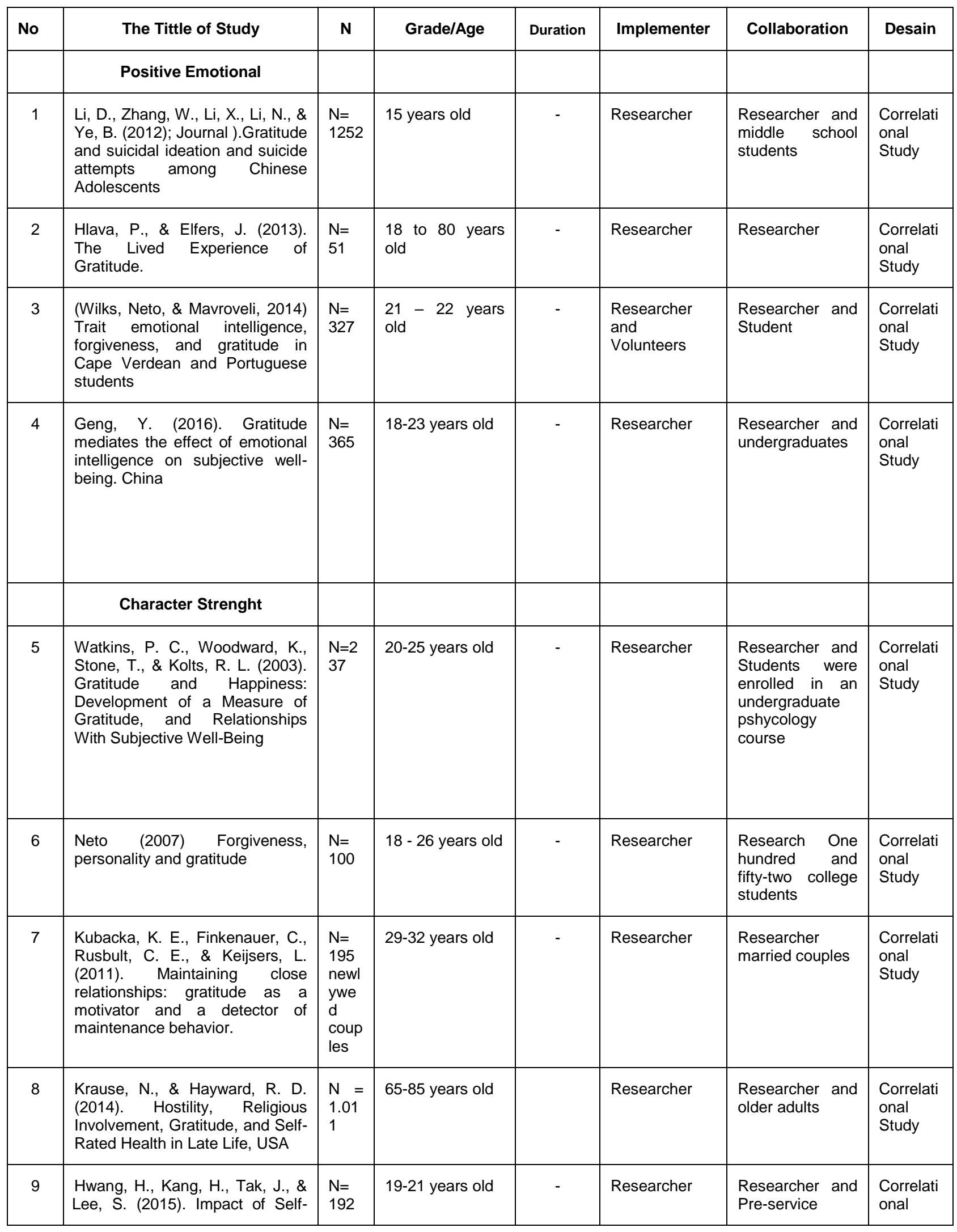


IJAEDU- International E-Journal of Advances in Education, Vol. III, Issue 9, December 2017

\begin{tabular}{|c|c|c|c|c|c|c|c|}
\hline & $\begin{array}{l}\text { esteem and Gratitude Disposition } \\
\text { on Happiness in Pre-service } \\
\text { Early Childhood Teachers. }\end{array}$ & & & & & $\begin{array}{l}\text { Early Childhood } \\
\text { Teachers }\end{array}$ & Study \\
\hline \multirow[t]{2}{*}{10} & $\begin{array}{l}\text { Zhou, X., \& Wu, X. (2016). } \\
\text { Understanding the roles of } \\
\text { gratitude and social support in } \\
\text { posttraumatic growth among } \\
\text { adolescents after Ya'an } \\
\text { earthquake: A longitudinal study }\end{array}$ & $\begin{array}{l}N= \\
315\end{array}$ & 12- 18 years old & - & Researcher & $\begin{array}{l}\text { Researcher } \\
\text { adolescent } \\
\text { survivors of the } \\
\text { Ya'an } \\
\text { earthquake. }\end{array}$ & $\begin{array}{l}\text { Correlati } \\
\text { onal } \\
\text { Study }\end{array}$ \\
\hline & Positive Intuition & & & & & & \\
\hline \multirow[t]{2}{*}{11} & $\begin{array}{l}\text { Naito, T., Wangwan, J., \& Tani, } \\
\text { M. (2005). Gratitude in University } \\
\text { Students in Japan and Thailand. }\end{array}$ & $\begin{array}{l}\mathrm{N}=4 \\
96\end{array}$ & 20 years old & - & Researcher & $\begin{array}{l}\text { Researcher } \\
\text { university } \\
\text { student } \\
\text { Japan in } \\
\text { Thailand }\end{array}$ & $\begin{array}{l}\text { Regressi } \\
\text { on and } \\
\text { Correlati } \\
\text { onal } \\
\text { Study }\end{array}$ \\
\hline & Intervention & & & & & & \\
\hline 12 & $\begin{array}{l}\text { Froh, J. J., Sefick, W. J., \& } \\
\text { Emmons, R. A. (2008). Counting } \\
\text { blessings in early adolescents: } \\
\text { An experimental study of } \\
\text { gratitude and subjective well- } \\
\text { being. }\end{array}$ & $\begin{array}{l}N= \\
221\end{array}$ & grades $6-7$ & $\begin{array}{l}3 \text { week } \\
\text { and } \\
\text { follow- } \\
\text { up. }\end{array}$ & $\begin{array}{l}\text { Experimenter } \\
\text { and Teacher }\end{array}$ & $\begin{array}{l}\text { Experimenter } \\
\text { Teacher and } \\
\text { student of early } \\
\text { adolescent }\end{array}$ & $\begin{array}{l}\text { Experim } \\
\text { ent }\end{array}$ \\
\hline 13 & $\begin{array}{l}\text { Froh, J. J., Kashdan, T. B., } \\
\text { Ozimkowski, K. M., \& Miller, N. } \\
\text { (2009). Who benefits the most } \\
\text { from a gratitude intervention in } \\
\text { children and adolescents? } \\
\text { Examining positive affect as a } \\
\text { moderator }\end{array}$ & $\begin{array}{l}N= \\
89\end{array}$ & $18-19$ years old & $\begin{array}{l}2 \text { weeks } \\
\text { and } \\
\text { (student } \\
\text { s were } \\
\text { given } \\
10-15 \\
\text { minutes } \\
\text { daily for } \\
5 \text { days } \\
\text { to either } \\
\text { write } \\
\text { their } \\
\text { gratitude } \\
\text { letter or } \\
\text { journal } \\
\text { about } \\
\text { daily } \\
\text { events. }\end{array}$ & $\begin{array}{l}\text { Experimenter } \\
\text { and Teacher }\end{array}$ & $\begin{array}{l}\text { Experimenter } \\
\text { Teacher and } \\
\text { student. }\end{array}$ & $\begin{array}{l}\text { Experim } \\
\text { ent }\end{array}$ \\
\hline 14 & $\begin{array}{l}\text { Rash, J. A., Matsuba, M. K., \& } \\
\text { Prkachin, K. M. (2011). Gratitude } \\
\text { and well-being: Who benefits the } \\
\text { most from a gratitude } \\
\text { intervention. }\end{array}$ & $\begin{array}{l}N=5 \\
6\end{array}$ & 22 years old & 4-week & Experimenter & $\begin{array}{l}\text { Experimenter, } \\
\text { the people were } \\
\text { recruited from a } \\
\text { small urban area } \\
\text { in British } \\
\text { Columbia, } \\
\text { Canada. }\end{array}$ & $\begin{array}{l}\text { Experim } \\
\text { ent }\end{array}$ \\
\hline 15 & $\begin{array}{l}\text { Flinchbaugh, C. L., Whitney, E., } \\
\text { Moore, G., Chang, Y. K., \& May, } \\
\text { D. R. (2015). Student Well-Being } \\
\text { Interventions: The Effects of } \\
\text { Stress Management Techniques } \\
\text { and Gratitude Journaling in the } \\
\text { Management Education } \\
\text { Classroom }\end{array}$ & $\begin{array}{l}N= \\
117\end{array}$ & 21-30 Years Old & 12-week & $\begin{array}{l}\text { Experimenter } \\
\text { and Teacher }\end{array}$ & $\begin{array}{l}\text { Experimenter } \\
\text { Teacher and } \\
\text { student who } \\
\text { undergraduate } \\
\text { business majors } \\
\text { from a large } \\
\text { Midwestern } \\
\text { university }\end{array}$ & $\begin{array}{l}\text { Experim } \\
\text { ent }\end{array}$ \\
\hline
\end{tabular}

